\title{
PENERAPAN STRATEGI RECIPROCAL TEACHING PADA PEMBELAJARAN KIMIA UNSUR DENGAN SISWA SEBAGAI MODEL DALAM UPAYA PENINGKATAN HASIL BELAJAR KELAS XII-IA SMA NEGERI 3 SURABAYA
}

\author{
Slamet H.Purwanto \\ Muslimin Ibrahim \\ Sri Poedjiastoeti \\ Program Studi Pendidikan Sains Pascasarjana Unesa \\ e-mail: H.Purwanto81@gmail.com
}

\begin{abstract}
This research to implemented of reciprocal teaching strategies with student as a model in the chemical elements to improved student learning outcomes. This research used pretest-postest group design, as the researched target was a XII-iA grade SMA Negeri 3 Surabaya. The instrument used is a sheet implemented plan, tests, and questionnaires. Techniques of data analysis was used to learn the application of the device by calculating the percentage and analysis of student learning outcomes, if student responses used student percentage opinion. The results on this research (1) includes complex plan-oriented learning tools to students reciprocal teaching as a model for 88,95\% and categorized well, (2) average student learning outcomes of both groups was 79.47, (3) the results of student responses showed $64 \%$ agreed and $32 \%$ most agreed if the reciprocal teaching strategies used in the study of chemical elements. Based on the above results the strategy of reciprocal teaching well performed, the results of both groups increased student learning, and as well as the students had a good response on reciprocal teaching strategies in the teaching of chemical elements.
\end{abstract}

Key words: Reciprocal Teaching, lesson plans, student learning outcomes, student response

\begin{abstract}
Abstrak: Penelitian ini bertujuan menerapkan strategi reciprocal teaching dengan siswa sebagai model dalam materi kimia unsur untuk meningkatkan hasil belajar. Desain yang digunakan dalam penelitian ini adalah pretest-postest group design, sasaran penelitian adalah siswa kelas XII-iA SMA Negeri 3 Surabaya. Instrumen yang digunakan terdiri atas lembar keterlaksanaan perangkat, tes, dan angket. Teknik analisis data yang digunakan yaitu menghitung persentase keterlaksanaan, analisis hasil belajar siswa, dan menghitung persentase pendapat siswa. Hasil-hasil dari penelitian ini adalah (1) keterlaksanaan perangkat pembelajaran berorientasi reciprocal teaching sebesar 87,38\% dan berkategori baik, (2) rata-rata hasil belajar siswa pada pembelajaran kimia unsur sebesar 79,47, (3) respon siswa sebesar 64\% setuju dan 32\% sangat setuju jika strategi reciprocal teaching digunakan dalam pembelajaran kimia unsur. Simpulan dalam penelitian ini adalah keterlaksanaan perangkat strategi reciprocal teaching terlaksana dengan baik, hasil belajar siswa meningkat dan siswa memiliki respon yang baik mengenai penerapan strategi reciprocal teaching dalam pembelajaran kimia unsur.
\end{abstract}

Kata-kata Kunci: Reciprocal Teaching, Perangkat Pembelajaran, Hasil Belajar, Respon Siswa.

\section{PENDAHULUAN}

Ilmu dapat diartikan sebagai suatu pengetahuan yang bersifat objektif, jadi dari sisi istilah IPA adalah suatu pengetahuan bersifat objektif untuk memperoleh pemahaman yang lebih mendalam tentang alam sekitar beserta isinya. Pengertian di atas sesuai dengan belajar melalui IPA (Learning through Science) (Ross, Lakin and Janet, 2010). Menurut Ross, dkk alasan mempelajari sains adalah

"They also need to appreciate that the process by which the ideas came into being, the very process of being scientific, forms an important part of their scientific education. These two facets - teaching science and teaching pupils - are at the heart of being a successful science teacher as a result of which the pupils in our charge can come to enjoy, understand, and use the scientific way of viewing their world."

Siswa perlu mengapresiasikan proses muncul ideide menjadi proses ilmiah, yang merupakan bagian penting dari pendidikan ilmiah siswa, serta guru sains bertanggung jawab atas hasil belajar siswa dalam memahami dan menggunakan cara ilmiah untuk melihat dunia mereka.

Hakekat IPA ada tiga yaitu IPA sebagai proses atau metode, produk, dan pengembangan sikap. (1) Proses atau metode merupakan langkah yang digunakan untuk menemukan, mengembangkan dan menerapkan produk sains, arti dari elemen proses adalah sains dapat dipelajari dengan berbagai metode pengetahuan. Proses atau metode berkaitan dengan keterampilan proses sains, yaitu seseorang akan mempelajari sains dengan menerapkan elemen sikap dan proses maka dari penelitian yang dilakukan akan menghasilkan sebuah produk baik dalam bentuk informasi, ide, fakta bahkan menghasilkan suatu konsep baru, (2) Produk adalah informasi, ide, fakta, teori, konsep, (3) Pengembangan sikap merupakan perilaku positif dalam mengembangkan rasa ingin tahu, 
mampu bekerja sama dengan orang lain, sikap termasuk dalam keterampilan sosial (Ibrahim, 2010: 1-2).

IPA memiliki beberapa rumpun pelajaran di antaranya kimia, oleh karenanya kimia mempunyai karakteristik IPA yaitu mencari jawaban atas pertanyaan apa, mengapa, dan bagaimana gejala-gejala alam yang berkaitan dengan komposisi, struktur (Permendiknas nomor 47, 2008:113).

Hasil angket dan wawancara bulan mei 2011 pada guru kimia di SMA Negeri 3 Surabaya yaitu setiap pembelajaran diperlukan suatu strategi belajar, melalui strategi belajar yang cocok dapat membantu siswa dalam memahami materi secara maksimal guna mencapai ketuntasan belajar, dan materi yang dianggap sulit adalah materi kimia unsur.

Salah satu strategi berorientasi pemahaman mandiri guna meningkatkan hasil belajar adalah strategi reciprocal teaching. Menurut Anne Marie Palinscar (1992) dari Universitas Michigan dan Ane Crown dari Universitas Illinois, USA, strategi reciprocal teaching merupakan strategi pembelajaran yang memusatkan perhatian kepada proses berpikir anak. Empat strategi pemahaman mandiri, yaitu (1) merangkum, (2) membuat pertanyaan, (3) menjelaskan kembali, dan (4) memprediksi, guru berperan sebagai fasilitator, pembimbing sedang untuk menjadi motivator, yaitu dengan cara memberikan yang menarik untuk dipelajari contohnya LKS, serta relevan dengan kebutuhan siswa (Palinscar dan Brown, 1984).

Berdasarkan uraian di atas peneliti mencoba menerapkan pembelajaran kimia unsur dengan menggunakan strategi reciprocal teaching guna meningkatkan hasil belajar. Maka penelitian ini berjudul "Penerapan Strategi Reciprocal Teaching Pada Pembelajaran Kimia Unsur Dengan Siswa Sebagai Model Dalam Upaya Peningkatan Hasil Belajar Kelas XII-IA SMA Negeri 3 Surabaya".

\section{METODE PENELITIAN}

Penelitian ini mempelajari penerapan perangkat strategi reciprocal teaching dalam pembelajaran kimia unsur di kelas XII-iA SMA Negeri 3 Surabaya. Penelitian ini ada dua kelompok yaitu kelompok eksperimen dan kelompok kontrol. Jenis penelitian ini adalah pre experimental design. Desain penelitian dapat dilihat pada Tabel 1.

Tabel 1. Desain Penelitian

\begin{tabular}{|c|c|c|c|}
\hline Kelompok & Pre-test & Perlakuan & Post-test \\
\hline Eksperimen (R) & $\mathrm{O}_{1}$ & $\mathrm{X}_{1}$ & $\mathrm{O}_{2}$ \\
\hline
\end{tabular}

Keterangan

Eksperimen (R) :Kelompok Kelas Eksperimen

SMA Negeri 3 Surabaya yang terpilih secara random (acak).
$\mathrm{O}_{1}$ : Kelompok kelas eksperimen diberi Pre Test sebelum menerima materi kimia unsur.

$\mathrm{X}_{1}$ : Strategi reciprocal teaching dengan siswa sebagai model

$\mathrm{O}_{2}$ : Kelompok kelas eksperimen diberi Pos Test setelah menerima materi kimia unsur.

Selama pengambilan data siswa diberikan materi kimia unsur, LKS, pretest-postest, sedangkan pada saat pembelajaran perangkat pembelajaran (RPP) akan dilakukan suatu pengamatan pembelajaran. Pada penelitian ini ada 2 tahap yaitu tahap persiapan dan tahap penerapan strategi reciprocal teaching. Perangkat pembelajaran akan dihitung keterlaksanaan perangkat dengan rumus

$\%$ Keterlaksanaan $=\frac{\text { banyak langkah yan g dirancang }}{\text { seluruh langks yan g dirancang }} \times 100 \%$

Pada proses pembelajaran siswa akan diberikan tes berupa pretest dan postest untuk mengetahui peningkatan hasil belajar siswa. Peningkatan hasil belajar siswa akan dihitung dari selisih skor pretest-postest.

Respon siswa dihitung melalui jumlah pendapat siswa atas pembelajaran yang berorientasi reciprocal teaching, dan disajikan dalam grafik lingkaran.

\section{HASIL PENELITIAN DAN PEMBAHASAN}

Hasil penelitian mengenai strategi reciprocal teaching, dan hasil belajar siswa di SMA Negeri 3 Surabaya dengan subjek penelitian sebanyak dua kelas XII semester II masing-masing kelas sebanyak 32 siswa. Instrumen yang digunakan dalam penelitian ini telah divalidasi dan di ujicobakan pada siswa kelas XII-iA. Pada penelitian ini yang menjadi subjek adalah kelompok belajar berorientasi reciprocal teaching yaitu kelompok dengan siswa sebagai model, materi yang dipelajari oleh siswa terdiri atas (1) Kelimpahan unsur golongan utama dan transisi, (2) Sifat fisis dan kimia unsur golongan halogen, dan (3) Unsur-unsur transisi. Hasil penelitian sebagai berikut.

\section{A. Keterlaksanaan Perangkat Pembelajaran}

Perangkat pembelajaran terdiri atas dua perangkat yaitu perangkat pembelajaran berorientasi reciprocal teaching (siswa sebagai model). Hasil penerapan perangkat akan dijelaskan pada Tabel 2

Tabel 2. Keterlaksanaan perangkat pembelajaran berorientasi reciprocal teaching

\begin{tabular}{|c|c|c|c|c|}
\hline & \multicolumn{4}{|c|}{$\begin{array}{c}\text { Perangkat Berorientasi Reciprocal Teaching } \\
\text { dengan Siswa sebagai Model. }\end{array}$} \\
\hline & \multicolumn{3}{|c|}{$\begin{array}{l}\text { Penilaian Keterlaksanaan Perangkat } \\
\text { Tiap Pertemuan dalam Persen }\end{array}$} & \multirow{2}{*}{ Kategori } \\
\hline & 1 & 2 & 3 & \\
\hline \multirow{2}{*}{ Rata-rata } & \multirow{2}{*}{84,23} & 83,36 & 94,55 & \multirow{4}{*}{ Baik } \\
\hline & & \multicolumn{2}{|c|}{ Rata-rata $=88,95$} & \\
\hline \multirow{2}{*}{ Reliabilitas } & \multirow{2}{*}{96,50} & 100 & 91,40 & \\
\hline & & \multicolumn{2}{|c|}{ Rata-rata $=95,7$} & \\
\hline
\end{tabular}


Pada Tabel 2 adalah hasil penilaian pengamatan keterlaksanaan perangkat pembelajaran berorientasi reciprocal teaching menunjukkan hasil keterlaksanaan tiga pertemuan, dari ketiga pertemuan dihitung rata-rata penilaian perangkat. Pertemuan pertama materi kelimpahan unsur golongan utama dan golongan transisi semua kegiatan pembelajaran dipimpin oleh guru, kegiatan pendahuluan sampai kegiatan penutup, pemodelan oleh guru pada pertemuan satu untuk memberikan contoh kepada siswa untuk menjadi model. Tahap pada pertemuan kedua dan ketiga materi sifat fisis dan kimia golongan halogen dan unsur-unsur transisi, guru memimpin pembelajaran di kegiatan awal, lalu pada kegiatan inti guru memilih salah satu siswa menjadi seorang model, dan pada kegiatan penutup guru yang memimpin kelas guna membimbing dan menutup pembelajaran. Penilaian persentase keterlaksanaan perangkat pembelajaran kelompok siswa sebagai model dari pertemuan satu sampai tiga masing-masing adalah $84,23 \%, 83,36 \%, 94,55 \%$. Hasil perhitungan rata-rata keterlaksanaan sebesar $88,95 \%$. Perhitungan persentase keterlaksanaan menunjukkan bahwa pemodelan oleh siswa pada pertemuan III sebesar 94,55\% dan semakin baik, selain siswa dan menunjukkan siswa dalam belajar unsur transisi mengikuti sintak dan strategi reciprocal teaching seperti menentukan ide pokok, membuat pertanyaan (questioning), klarifikasi pertanyaan (clarifying issue), merangkum (summarizing) dan memprediksi materi selanjutnya (predicting), dengan hasil ini siswa mampu mempelajari suatu materi unsur transisi meskipun materi transisi merupakan materi yang lebih sulit dibandingkan materi kelimpahan unsur-unsur golongan utama-transisi dan unsur-unsur transisi Menurut Efendi (2005) bahwa perangkat yang dikembangkan dan yang diterapkan dengan menggunakan pendekatan pengajaran terbalik dapat meningkatkan ketuntasan hasil belajar, dan Masmiatin (2006) berpendapat bahwa pembelajaran dengan menggunakan strategi reciprocal teaching siswa menjadi aktif dalam belajar serta siswa mampu menemukan konsep guna membangun makna atau pemahaman secara sendiri.

\section{B. Hasil Belajar Siswa}

Hasil belajar siswa berupa gain antara hasil pretestpostest kelompok ekperimen dan kelompok kontrol. Instrumen tes yang digunakan pada penelitian ini telah divalidasi dan di ujicobakan pada kelas XII-iA. Penelitian berupa kelompok belajar yaitu kelas yang dipilih secara acak, sebagai kelompok belajar berstrategi reciprocal teaching dengan siswa sebagai model.

Kelompok belajar berstrategi reciprocal teaching diberikan suatu soal tes untuk mengetahui hasil belajar

\begin{tabular}{|l|c|c|c|}
\hline & \multicolumn{3}{|c|}{ Skor Kelompok Belajar dengan Siswa Sebagai } \\
Model
\end{tabular}

Penerapan Strategi Reciprocal Teaching Pada Pembelajaran Kimia Unsur Dengan Siswa Sebagai Model Dalam Upaya Peningkatan Hasil Belajar Kelas XII-IA SMA Negeri 3 Surabaya siswa. Tes yang diberikan adalah soal pretest dan soal postest. Soal-soal pretest dan postest dianalisis kelayakan instrumen tes dengan hasil 1,0. Berikut adalah rerata hasil belajar kedua kelompok dilihat pada Tabel 3 .

Tabel 3. Rerata Skor Hasil Belajar dengan Siswa Sebagai Model

Berdasarkan Tabel 3 menunjukkan rata-rata nilai pretest kelompok sebesar 50,66, sedangkan pada skor postest sebesar 79,47, dan hasil rata-rata peningkatan hasil belajar sebesar 29,44. Pada hasil ini $100 \%$ siswa tuntas

Nilai postest pada kelompok belajar berorientasi reciprocal teaching dengan siswa sebagai model menunjukkan nilai yang besar, hasil ini menunjukkan materi kimia unsur dapat dipelajari dengan mudah. Menurut Masmiatin (2006) pembelajaran dengan menggunakan strategi reciprocal teaching dapat meningkatkan hasil belajar, secara klasikal ketuntasan belajar mencapai $92,5 \%$.

\section{Respon Siswa}

Data hasil respon siswa mengenai pembelajaran yang berorientasi strategi recipocal teaching terlihat secara ringkas pada Gambar 1

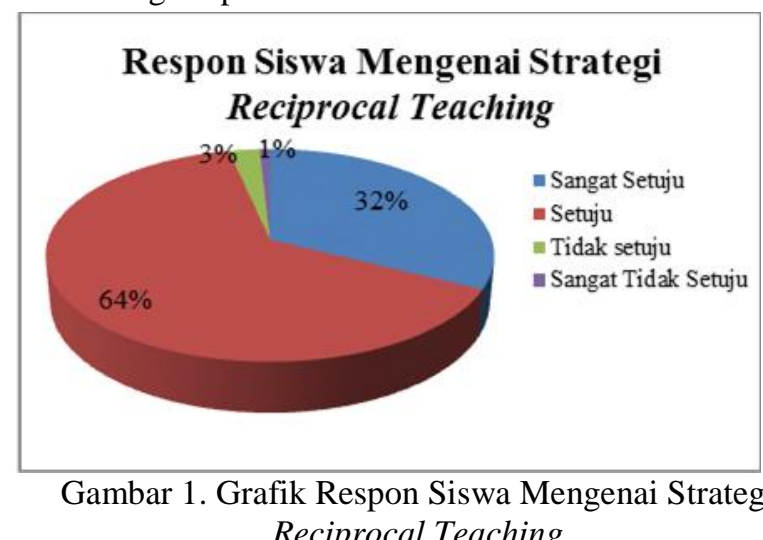

Pada Gambar 1. Pada gambar tersebut semakin jelas menunjukkan bahwa penerapan strategi reciprocal teaching setuju jika digunakan pada pembelajaran kimia unsur, dan siswa merasa mudah dalam memahami materi kimia unsur di setiap bacaan, karena di setiap bacaan siswa menentukan ide pokok yang dapat memperkuat pemahaman secara mandiri dan semakin siswa paham atas bacaan yang diberikan maka dapat meningkatkan hasil belajar siswa.

\section{SIMPULAN}

Berdasarkan hasil analisis data dan pembahasannya pada pengambilan data dapat diungkapkan beberapa simpulan sebagai berikut:

1. Keterlaksanaan perangkat berorientasi reciprocal teaching terlaksana dengan baik pada kedua kelompok belajar yaitu sebesar $88,95 \%$ pada 
kelompok siswa sebagai model, dan perangkat berkategori baik.

2. Rerata hasil belajar kelompok dengan siswa sebagai model sebesar 79,47 dan gain hasil belajar sebesar 29,44

3. Respon siswa menunjukkan Hasil respon siswa menunjukkan $64 \%$ setuju jika strategi reciprocal teaching digunakan dalam pembelajaran kimia unsur dan $32 \%$ sangat setuju.

\section{DAFTAR PUSTAKA}

Arikunto, Suharsimi. 2006. Prosedur Penelitian Suatu Pendekatan Praktik edisi revisi VI. Jakarta: Rineka Cipta.

Brown, Ann L.1992. "Design Experiments: Theoretical and Methodological Challenges in Creating Complex Interventions in Classroom Settings". The Journal of The Learning Sciences. Vol 2 No.2 Lawrence Erlbaum Associates, Inc 1992. pp.141178

Chang, Raymond. 2003 Kimia Dasar Konsep-Konsep Inti, Edisi 3 jilid 1. Bandung: Penerbit Erlangga.

Depdiknas. 2006. Silabus Mata Pelajaran Kimia. Jakarta: Direktorat Jendral Manajemen Pendidikan Dasar dan Menengah Direktorat Pembinaan Sekolah Menengah Atas.

Dharma, Surya. 2008. Kriteria dan Indikator Keberhasilan pembelajaran. Jakarta. Departemen Pendidikan Nasional. Diakses http://www.lpmpjogja.diknas.go.id/materi/fsp/2009Pembekalan-Pengawas/21 -- KODE -- 04. 10 April 2011. Jam 10.30

Efendi, Nur. 2005. "Peningkatan Ketuntasan Hasil Belajar pada Pokok Bahasan Perkembangbiakan Tumbuhan dengan Penerapan Pendekatan
Pengajaran Terbalik". Tesis Magister pendidikan, Universitas Negeri Surabaya.

Ibrahim, Muslimin. 2008. Pembelajaran Sains Reciprocal Teaching. Diakses http://sainsmuslimin.blogspot.com/. 09 April 2011. Jam 13.15

Ibrahim, Muslimin. 2010. Dasar-Dasar Proses Belajar Mengajar. Surabaya: Unesa University Press.

Lee, J.D. 1991. Concise Inorganic Chemistry. London: Chapman \& Hall

Masmiatin. 2006. "Pengembangan Perangkat Pembelajaran Biologi SLTP dengan Penerapan Strategi Reciprocal Teaching". Tesis Magister Pendidikan, Universitas Negeri Surabaya.

Palincsar, A. S., and Brown, A.L. 1984. "Reciprocal Teaching of Comprehension-Fostering and Comprehension-monitoring activities". Cognition and Instruction. Vol 1 No. 2. Lawrence Erlbaum Associates, Ins 1984. pp 117-175

Ross, Keith., Lis Lakin, Janet Mc Kechnie. 2010. Teaching Secondary Science Constructing Meaning and Developing Understanding (Third Edition). USA: Routledge 270 Madison Ave, New York, NY 10016.

Seymour, J.R., Helena, P.O. 2002. "Reciprocal Teaching Procedures and Principles Two Teachers' Developing Understanding". Teaching and Teacher Education.Vol 19 Elsevier Science Ltd 2003. pp 325-344.

Sugiarto, Bambang. 2009. Sistem Periodik Unsur. Surabaya: Unesa Press.

Utami. 2008. "Pembelajaran dengan Strategi Pengajaran Terbalik pada Matakuliah Biologi Umum Program Studi Pendidikan Matematika STKIP-PGRI Tulungagung". Tesis Magister Pendidikan, Universitas Negeri Surabaya. 